\title{
Codex Alimentarius : Indonesia's Halal Food Challenges as Culture Identity in International Trade
}

\author{
Arin Fithriana \\ International Relations Department \\ Budi Luhur University \\ South Jakarta, Indonesa \\ arin.fithriana@budiluhur.ac.id
}

\author{
Jeannie Annissa \\ Communication Science Department \\ Budi Luhur Univerity \\ South Jakarta, Indonesia \\ Jeannie.Annissa@budiluhur.ac.id
}

\begin{abstract}
The existence codex alimentarius provisions comformity with the provision of halal food product certification, for Muslims, is profitable. However, with the majority of the Muslim population as part of the Indonesian identity, it cannot put Indonesia as a country with the number of certified halal food products. There are still efforts, both external and internal to address these challenges. Using qualitative methods, the analyzed secondary data are described using diplomacy concept to show the Indonesian government's efforts in international institutions and regimes such Codex Alimentarius Commission (CAC). While at the domestic level, secondary data analysis is described through the concept of competitive advantage as a way to improve the competitiveness of Indonesian halal food products. Based on analysis, the halal food in Indonesia affected by the ambiguence of itself definition. But in the other hand, the tolerance level of Indonesian toward halal food is high. So, Indonesia government should adjust the concept of halal food by giving halal licence, and develop the societies to improve halal food products. In other words, by increasing halal food products as Indonesian identity and culture, it should raise competitive advantage on the quality and quantity of halal commodity products in the market (market based view) and increasing consumer and producer understanding on halal food product management as Indonesian resources (resources based view).
\end{abstract} food

Keywords-Codex alimentarius; competitive advantage; halal

\section{INTRODUCTION}

Indonesia is a country with a majority of Muslims. It's no wonder food needs are also adjusted to the conditions and values which adopted by the majority of Indonesian people. Halal is an Islamic terms to what food is permissible or lawful based on Quranic teaching. Therefore, it can be said that food acn be classified as the identity and culture of a region. As Kathryn, et.all, food habits or food culture refers to the way in which humans use food from the way of choosing, obtaining, distributing, preparing, serving and eating. Based on this concepts the food is also indirectly part of the identity and culture of Indonesia. As in the Middle East, eating pork can be assumed to be non-Muslim. As an identity, halal food has become commonplace in the culture of society. Because it has become commonplace, there is a belief in halal food circulating in the community.
Trust is demonstrated by no proof through certificates on the offered food. On the other side, in international trade, to protect consumers toward safe products, regime is formed which is also a cooperation between WHO and FAO that CAC. This regime requires provisions on food products that categorized as safe for human being and environment. The proof for categorized safe product is certification. As well with halal food products, that to be widely accepted, must fullfil the provisions of the Codex. This condition also encourages the state to develop halal certification department.

The existence of the regime also encourages manufacturers to meet standards including halal food products. For Indonesia, where halal food becomes a necessity and identity, of course, this becomes a challenge considering the food product itself as well the challenge for the food industry become part of international trade commodity. To achieve such states where Indonesia's halal food products can be widely accepted on international trade, there must be a competent certification. Therefore, this paper focuses on how Indonesia respond to Codex Alimentarius as the development of halal food which has been set up in the year 1997.

The contents of the codex include the definition of halal and its use on product packaging to indicate the halalness of a product. Indonesia is not moslem country, and Islam is not part of local culture. Pluralism in Indonesia affects the understanding of halal food. To answer and analyze the problems, this research emphasis the concept of competitive advantage. This is because halal food products are categorized as part of local culture. Local culture is a distinguishing identity from other products. In international trade, identity and local culture as a part of competitive advantage.

\section{DISCUSSION}

As explained before, local culture and identity are part of competitive advantage. Halal food products can be categorized as competitive advantage. The collision with the international regime occurs when halal Indonesian food products are included in international trade. This means only when faced with the same commodities from international trade. This is what underlies $\mathrm{CAC}$ as a challenge for the development of halal products as part of the local culture. With the flow of thought as follows: 


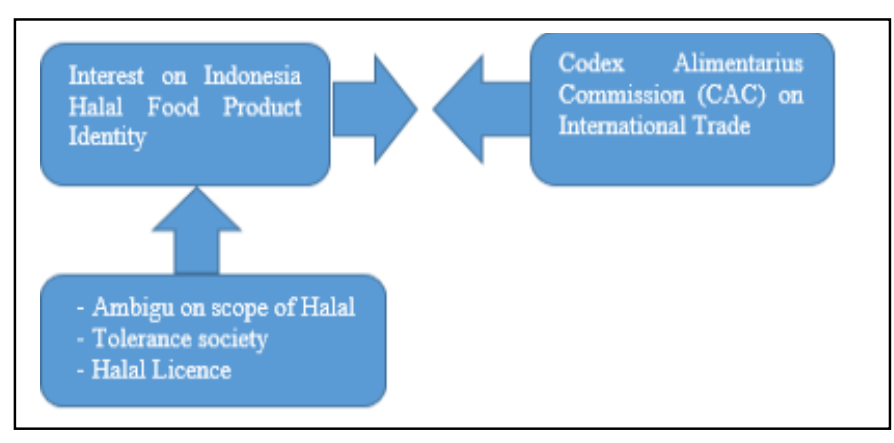

Fig.1 Flow of thought

Discussion of Indonesia's policy to handle this challenge is divided into two. First is external point of view which based on market based view (MBV) and internal challenges outlined on resources based view (RBV). Explanation of the discussion using qualitative methods based on secondary data which obtained from documents, references and news. While the type of research is descriptive analysis, in terms of describing the reality based on data obtained with the framework of theory and concept analysis used. The concepts and theories used is competitive advantage. This research analysis uses this concept to facilitate the categorization of the challenges handling by Indonesia as mentioned above.

Based on this concept, external challenges rise as part of government efforts to fulfill regime requirement. While on the internal challenges emphasize the preparedness of internal conditions strategy to fulfill regime provisions and international trade markets globally. The existence of this codex will inevitably have to be met by food products including Indonesia's halal food products.

\section{A. Resources Based View (RBV)}

Indonesia's advantage as an agricultural country that produces food products gained from agricultural, plantation, fishery and animal husbandry. The results of such activities are easily distinguishable between halal and non-halal. The existence of globalization and the development of international trade's provisions, it must consider Codex alimentarius provision, which related to the process of packaging and distribution of products. So, to be competitive, Indonesian food commodities must consider the provisions to be accepted international market.

Although Indonesia is a predominantly Muslim country, it does not mean that awareness and understanding of the use of halal food products is in high condition. The establishment of a halal certification body is an appropriate step. But there are still some weakness on it. Such rules that have not been comprehensive and weak monitoring yet. Since halal certification institution was formed in 1989, it was at 1994 had issued halal certification. Until 2015, out of the total certification issued, only about 9 percent are not food products or food providers (restaurant). It can be said that the attention and the need for halal food is quite large. In addition, because the certification is only valid for 2 years, it is necessary on monitoring of food products in circulation. Entrepreneurs or producers are expected to have awareness to re-register their food products or business.

While, on the consumer, the pluralism of society and culture affects the understanding of halal food products. For example, in some communities in Indonesia, there is a habit of eating animal blood, called marus, which is categorized as halal (beef, buffalo, goat, chicken). Being accustomed, it is often assumed that marus is halal. Until now, the culture is still accompanying the implementation of religious provisions including halal. in the following table Referring to the data on the world's halal market variation, Indonesia as part of multicultural category as the basic condition and part of the resource.

Table 1. Variations in Global halal market

\begin{tabular}{|c|c|c|}
\hline \multicolumn{3}{|c|}{ Regional variations in global halal market } \\
\hline $\begin{array}{l}\text { Multicultural } \\
\text { (ag Malosoria Singapores) }\end{array}$ & $\begin{array}{l}\text { Muslim majority } \\
\text { (os } 6 C C \text { ooumtrios) }\end{array}$ & 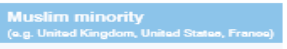 \\
\hline $\begin{array}{l}\text { - Mixed religion \& culture } \\
\text { - Well-established Muslim } \\
\text { presence } \\
\text { - Pioneered standards \& } \\
\text { certification } \\
\text { - Consume \& produce } \\
\text { - Multinational presence } \\
\text { - Local SMEs \& microenterprises } \\
\text { - Halal as economic driver } \\
\text { - Halal as political platform }\end{array}$ & $\begin{array}{l}\text { - Traditional Muslim majority } \\
\text { population } \\
\text { - Halal low priority - assumed } \\
\text { to be halal } \\
\text { - Primarily consumers } \\
\text { - Exporters target market } \\
\text { - Slow to develop standards } \\
\text { - Political support starting } \\
\text { - Multinational presence } \\
\text { - Developing local industry }\end{array}$ & $\begin{array}{l}\text { - Immigrant Muslim minorities } \\
\text { - Political sensitivity } \\
\text { - Halal as identity } \\
\text { - Disposable income } \\
\text { - High industry interest } \\
\text { - Multinational headquarters } \\
\text { - Consumer awareness } \\
\text { - Marketing expertise } \\
\text { - Innovation \& creativity } \\
\text { - Global influence }\end{array}$ \\
\hline
\end{tabular}

In mixed religion and culture, it shows that high tolerance pluralism can be used as capital to support halal food development in Indonesia, because Muslims in Indonesia are not only as a majority group but also as a civil society group which capable on influencing and playing a role in government policy (well-established muslim presence). Based on this condition, the Muslim group develops pioneered standards and certification since halal food consumers became very large, as the food producers supported by agrarian conditions (consume and produce). Halal food products have become part of international trade provisions, mainly listed in alimentarius codex, this provision is part of the provisions of the international trading regime which is also part of the polical platform. By means, international actors can use this halal issue as part of a political policy to achieve their goals and interests.

Based on these insights, ideally Indonesian halal food products are capable of competing on international trade, because of resources and raw materials are available readily and easily found in Indonesia. In this case, halal certified could be economic driver. However, the challenge on providing and developing halal food products is not only related to he fulfillment of food needs, but also in providing halal certification on food products. The number and variety of food, whether processed or not are very much. Coupled with the existence of food and imported food products require supervision and attention from the government related to certification or halal label. The Indonesian Council of Ulama 
(MUI), in collaboration with the Food and Drug Analysis Agency (LPPOM) and the Food and Drug Analysis Agency, is the only national certifier. LPPOM MUI was established in 1998 , on fulfilling the function, conducting cooperation with the Ministry of Religious Affairs, Ministry of Agriculture and Ministry of Cooperatives and SMEs, Ministry of Trade, Ministry of Industry, Ministry of Marine Affairs and Fisheries, Ministry of Tourism and Creative Economy and a number of universities in Indonesia.

Apart of its own halal certification, LPPOM MUI recognizes other halal certificates which issued by organizations that have been approved and approved by MUI either. In 2017, the Ministry of Religious Affairs of the Republic of Indonesia took over the halal certification by establishing the Product Guarantee Organizer Board (BPJPH). The new agency will facilitate the halal certification administration process, which involves receiving all applications, collecting fees, and issuing certificates. The role of MUI is limited to issuing fatwas and conducting the audit process, which will also be provided to other organizations such as universities and civil society to speed up the work. Based on MUI data from 2012 to October 2017 the number of products that have been obtained halal certification amounted to 259,984 products. Halal certification is valid for only two years and should to be re-registered or revoked for certification.

The existence of globalization and diverse food demand encourage the import of food, including halal food. In this regard LPPOM MUI has cooperated with foreign certification bodies from other countries that have been deemed competent. So that on imported food that has been certified by these institutions only get supervision from LPPOM MUI. And as for imported food that has not been certified or halal labeled, the importing companies are expected to have the eagerness or volunteer to register the food commodities. This volunteerism means there is no compulsion for importers. So in this condition, the consumer needed carefulness to choose food. The halal certification which obtained by imported food has the same behave and applied with domestic food certification, ie with a period of 2 years and then re-register the commodity. If within 2 years does not re-register the commodity or if the condition after the commodity been reviewed is not in accordance with Islamic norms, so the food commodities can be withdrawn from the market.

Based on data from BPS (Statistics of Social Affairs) relating to imports of total consumer goods is totaling 10.875.500 million US dollars (including for fuel and transport), whereas without fuel and transportation it reached $8,727,800$ million US \$. Based on a report from Global Halal Food Trade, the value of Indonesian food imports reached 14.3 billion US dollars. The share of 7.4 percent of total consumption of halal food reached 193.6 billion US dollars in 2015. Although Indonesian product as part of product market share, but when it compared with the amount of value imports on consumer goods is still in low condition.
The analysis through resources based view is based on the difference between the need of Indonesia's halal food and the import of Indonesia's halal food. The need for halal Indonesian food is 157 billion US\$ while halal food import is only 14.3 billion US \$. With the difference of 142.7 US\$ it can be said that RBV of Indonesia's halal food products are competitive because it value is bigger than import.

\section{B. Market Based View (MBV)}

Referring Porter's view on the market based view that in this model explains the five external drivers that must be considered by an organization in order to be able to gain a competitive advantage in the business environment, namely the threat of new players in business, competition among companies in the industry, replacement product or service, supplier strength, and buyer power. Based on this scope, in order to gain competitiveness, the halal food products of Indonesia should pay attention to external conditions, especially with the presence of halal products certified in international trade. Countries that have bodies or institutions authorized to certify halal are not only dominated by countries with a Muslim majority. Several countries in Asia and Europe have developed halal certification institutions even though the country is predominantly non-Muslim. For examples in Asia there are Thailand, Taiwan, Hongkong and Japan while in Europe there are Belgium, Poland and the Netherlands, even the United States.

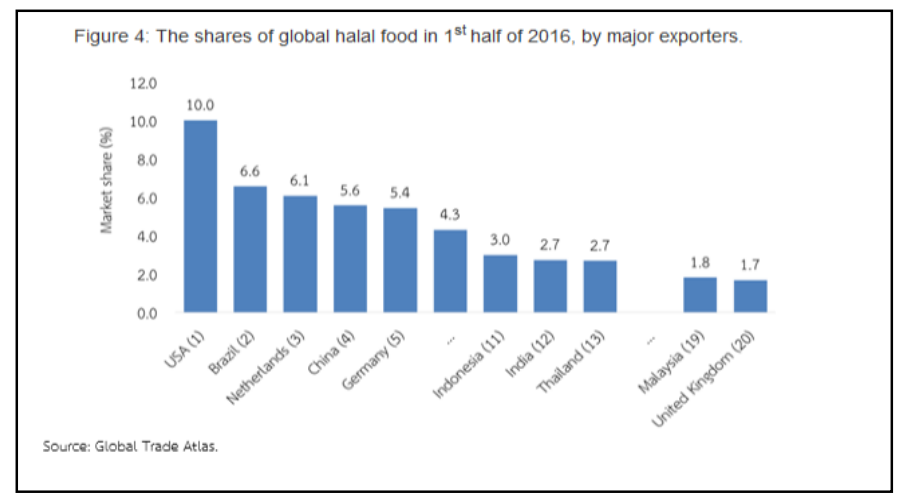

Fig 2. The Share of Global Halal Food

With the existance of halal certification institution by the country, the food products which has been producted could be certified indirectly. This condition could become a competitor for Indonesia's halal food products. This can be seen in Figure 2 which shows that the United States as the main exporter of halal food products of the world and Indonesia as a Muslim majority country only occupies at the eleven position, which is only $3 \%$.

Indonesia is the largest food market among other member countries of Islamic cooperation. This means that if Indonesia does not immediately improve its competence, it will be difficult for Indonesia to become a leader in the trade of halal food products of the world. The population of Indonesian Muslims is about 85 persen of the total population of 
Indonesia. This means that if the number of Indonesian population in 2017 about 256,603,197 inhabitants, then the number of Muslims about 218,112,717 inhabitants. This number is one third of the world's Muslim population, which is 3 persen. The domestic halal food market of Indonesia is quite large, so it is actually quite easy for Indonesian halal food producers to market their food products in the domestic country considering the need is also quite large. In addition, with the globalization and the shifting of understanding and trend in the use of halal food products, so that the market share is not only limited to Muslim countries, but also there are other potential markets with non-Muslim consumers. This is shown in Figure 3 below:

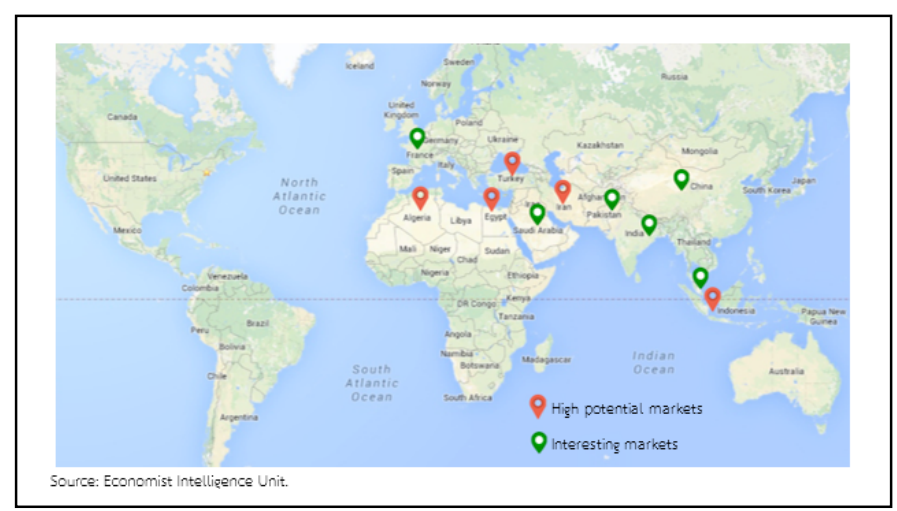

Fig 3. Overview of the Potential and Interesting Halal Food Market in the World.

In the picture can be explained that the interesting market is a market share that needs to be targeted by Indonesia's halal food commodities. By utilizing natural resources, it will be very beneficial for Indonesia. Potential market, as the term, needs to get attention by Indonesia's government to develop Indonesian market. Market based wiew is based on secondary data by comparing the percentage of halal food products in the world (share of halal food exporter), with percentage of 3 persen and percentage of Indonesian halal food consumers, taken from the number of Indonesian Muslims about 3 persen. So, the Indonesia's halal food products based on MBV are stagnant. This stagnant explanation is not uncompetitive at all. This is essentially that Indonesia has considerable potential in developing certified halal food products which is supplied and supported by an agrarian culture.

This is one thing that Government of Indonesia has done is actively involved in CAC.Thus indirectly, it could put in Indonesia's national interests in the regime. In other words, Indonesia can easily monitor any developments that occur in CAC. At the 2017 CAC meeting Indonesia was elected one of the Vice Chairs in CAC. This shows the active involvement of Indonesia as a country with a large population, including the majority of Muslims. This means that if food products including halal food have been fulfilled the provisions in $\mathrm{CAC}$, so to get halal certification just one step away. Although halal certification needs to get recognition from competent institutions, Indonesia's involvement in world Halal forums is one thing could be exploited. Although in some of the assessment of the scope and the scope of what is halal or halal definition has not reached on agreement. This means that between Muslim countries (Muslim groups) has not reached an agreement on technical details of goods and services categorized as halal. Simply put, it is said technical details because if only define, then the simple definition is in the provisions of Islamic Sharia namely at the Qur'an. But when implemented in everyday life it is not as simple as the scope of definition. This is because of food, both unprocessed and processed by a complex process. For example, in fruits, in general, most of the fruits are halal products. But if in the process of cultivation using manure from cattle category of forbidden, then the product becomes complex because of differences in opinion between the fruit remain as halal food or as part of the illicit product. Included in foods that use dairy products, cheese, gelatin or rum. Even on the more complex issues, mention that the so-called halal is if in the process is not disgusting. Because the disgusting thing is also included in the category of haram. For example, on food products Belacan or shrimp paste made of shrimp or fermented fish, produce a product that looks casual looks disgusting because of the change of colour and smells. So some communities mention this food product is categorized not halal. But for some Asians who are used to using belacan or shrimp paste in processed, this is not disgusting. The difference of halal perception is then the challenge itself,

As mentioned that halal food products as part of the identity should be raised its competitive advantage. Quoting from Porter that to increase the competitive advantage required a MBV and RBV. In MBV, it is necessary to see international acceptance of Indonesia's halal food products and its use at the domestic level. It is contradictory that although Indonesia as a Muslim mayority, but Indonesia's halal food products have not dominated the international market. This means that although the majority does not mean Indonesia dominated halal food products. According to SGIE 2017 report, Comodity for halal food was dominated by UEA. Althougt Indonesia was part of 15 th countries on halal countries. Halal food commodity is not a monopoly by Muslim consumers. This is because the awareness and consumer trends on safe food. Safe food products have been arranged in CAC. And to note that to comply halal provisions, then indirectly the product has been fulfilled its CAC provisions. Based on this is, the halal food products increasingly sought after by consumers who are not just Muslims. For food needs, Indonesia can fulfill itself from within the country, although there are some food commodities are imported.

Commodities for domestic needs somewhile differ from export requirements. Export requirements must meet the requirements of the international regime, while domestic commodities are sufficient to meet the requirements set by the government. As explained earlier that the majority of the 
Muslim population of Indonesia is supplemented by the geographical conditions that agriculture support the fulfillment of food needs, as well as the high tolerance between community that have been developed before Indonesia's independence. So, to meet the needs of both natural and processed foods based solely on trust. Halal certification from a competent institution is not yet a matter to look out for a guarantee of products including halal food products. The guarantee is still about the security and health issued by BPPOM. However, it does not mean that the Indonesian government does not stand idle. Through BPPOM, LPPPOM MUI, and several ministries seek to improve halal certified food products. On the halal directory 2011, reported that amount of halal sertified company about 1.460 companies and 3.131 products sertified by LPPPOM MUI Province. With the large number of food products that have been certified, it is expected that Indonesian halal food products become internationally taken into account commodities. This explains that in competitive advantage, a competent control body and sectoral cooperation is required to improve and monitor the number of certified food products for both domestic and international commodities. On the other hand, education is needed for producent and consument to more careful and certify their food products.

\section{CONCLUSION}

Briefly, as an agrarian country with a majority of Muslims gained by government support, Indonesia has the potential capability to become the world's leading exporter of halal food. Raw materials food is existed and already available in Indonesia. In international trade, the competition of food commodities is not only halal, but it also the needs of creativity in managing food commodities that become interested in the market. Halal food RBV Indonesia is quite competitive and be able to improve the competitiveness of Indonesia. Or in other words the implementation of halal food policy of Indonesia should be encouraged and get support from all parties to improve the competence of MBV. Indonesia needs to improve the quality of food commodities in general and not just on halal food. It should be noted that some developed countries with non-Muslim majority are more interested in halal food because it is considered more secure and has passed several inspection and supervision processes. Thus this condition can be a driver for halal Indonesian food business to compete and improve its competitiveness.

And should to be noted, that by actively engaging international institutions and regimes, Indonesia has more opportunity to know the direction, prepare and introduce Indonesian halal food products as part of local identity and cultures. This has been done by Indonesia in Modest fashion which has been accepted by international market as part of Indonesian identity. To support the achievement, it is necessary to increase the competitive advantage of halal food products of Indonesia by improving the quality and quantity of certified halal food products for both domestic and international consumption.

\section{REFERENCES}

[1] Adisasmito Drh. Wiku, M.Sc, Ph.D, (MUI National Policy Analyzis and Food Drug Analyzis Agency on Food and Drug Labelling) "Analisis Kebijakan Nasional MUI dan BPOM dalam Labeling Obat dan Makanan, Fakultas Kesehatan Masyarakat," Health Community Faculty, Indonesia University, 2008.

[2] Agnieszka Siewicz, Anthropology as an Inspiration to Food Studies: Building Theory and Practice, Anthropowebzin, 3/2011

[3] Anil K Gupta, , et all, "The Quest for The Global Dominance: Transforming Global Presence into Global Competitive Advantage", (2nd edition) San Francisco: John Wiley \& Sons 2000, pp.51-9.

[4] International Trade Center, "From Niche to Mainstream; Halal Goes Global,” Geneva, Switzerland, 2014, p. 25.

[5] Kuhnlein V, Harriet et.all, "Indigenous People's Food System and Wellbeing: Interventions and Policies for Healthy Communities," Rome: FAO, 2013.

[6] Lady Yulia, (Halal Lifestyle Globally), "Halal Lifestyle Makin Mendunia," Islamic Paper, (not published), Padang: Universitas Andalas. 2015, p. 1.

[7] State of Global Islamic Economy Report 2016/2017

[8] Export Bulletin, Warta Ekspor, Ditjen PEN/WRT/56/VII/2015 July Edition.

[9] Halal certification by Islamic Indonesia Council (MUI) [Online]. Avalaible:

http://www.halalmui.org/mui14/index.php/main/go_to_section/2/31/pag $\mathrm{e} /$.

[10] “About Codex," [Online]. Avalaible: http://www.fao.org/fao-whocodexalimentarius/about-codex/en/.

[11] "Population Growth," [Online]. Avalaible: https://www.bps.go.id/linkTabelStatis/view/id/1040.

[12] "Drug and Food Supervision," [Online]. Avalaible: http://www.pom.go.id/new/index.php/view/latarbelakang.

[13] "Indonesia Halal Food Import," [Online]. Avalaible: http://www.ekonomisyariah.org/6138/impor-pangan-halal-indonesiacapai-143-miliar-dolar/.

[14] "Business Strategy, Time, “ [Online]. Avalaible: www.jakartaconsulting.com/publications/articles/businesstransformation/strategi-diantara-dua-kubu. 